\title{
Conceptual Model of Relation Between Policies of Comprehensive Growth In National Development Plans With Economic Stability In Rural Spaces
}

\author{
Mohamad Hajipour \\ Ph. D. Student of Geography and Rural Planning, Kharazmi University, Tehran, Iran
}

\begin{abstract}
Villages and rural economics have a unique role in the process of spatial development. Economic prosperity is required to be integrated with the expansion of different economic activities in rural areas to access economic development and stability of these rural settlements. In this paperfor assist the process of sustainable rural development, we have tried to drawing conceptual model of relation between policies of comprehensive growth in national development plans with economic stability in rural spaces.
\end{abstract}

Keywords:- National Development Plans, Economic Stability, Sustainable rural development.

\section{INTRODUCTION}

Sustainable rural development is an integral part of development process that can result in life improvement and achieving social justice (Thompson, 1999: 8). As a relatively new approach towards the satisfactory growth and alteration of rural settlements, sustainable rural development can be defined as a process of realizing the future dreams of rural residents (Elands \&Wiersum, 2001:5) along with a wide range of deep changes in order to improve the quality of rural lives to establish a continuous welfare of social, economic, and environmental values (Torjman, 2002: 2; Ezeala - Harrison, 1996: 72). It is noteworthy that achieving sustainable development depends on things like recognizing existing problems in different aspects of sustainable development, making kinds of promoting and organizing interactions among its different aspects with emphasis on making welfare for all members of the society (Anriquez\&Stamoulis, 2007: 24; Dalal-clayton \& Bass, 2002: 12).Among the usual concerns of development custodians and program makers, especially in developing countries where development spatial-location gaps between cities and villages is more than other societies, there is a predominance of rural settlements development. In this case, a major part of the national development process and job creation will be done by the rural spaces (Ake, 1996: 14; King, 1983: 5; Todaro, 1992: 48; Bruckmeier\& Tovey, 2009: 60; European Communities Commission, 2007: 335). In fact, due to the unique role of villages in mobility and regularity of the land spatial organization, also some functions like space reconstructing process (country), direct exploitation of natural environment capacity (especially remote areas), providing food security, the existence of poverty in villages that necessitates its elimination, and its impact on GNP $\{=$ gross national product $\}$, great importance has been allocated for the matter of rural development (Rezvani, 2003: 269; SoltaniMoghadas, 2013: 159).

Barriers and problems to which people who are living in rural settlements are exposed, can be classified into social, cultural, economic and physical areas. Among these classifications, economic challenges of rural space play a basic underlying role over the other groups (Vidican, 2009; Pa sakarnis\&Maliene, 2010). In fact, because in some countries like Iran, agriculture consists great centrality in the structure of spatial development in rural areas and it is the only as well as the most important principle in the economic development of villages in most development plans (Taherkhani, 1993: 21), lack of diversity in economic contexts and job opportunities in rural areas are among those undeniable facts whose consequences can be summarized in unemployment, decrease of investment efficiency, instability in the source of income, weakening of rural economy and culture, rural- urban migrations, vulnerability of rural economy and instability in rural life and economy (Javan et al.,2011: 19). In other words, disruptionin theorganizationof economyin ruralspaces and also its exhaustion and traditional structure caused not only the lack of progress in rural economy but also weakening the basis for the development of other areas.Modifying the organization of space economy in rural spaces depends on different underlying and hardware actions to achieve economic stability and sustainable rural development. But, the first and most fundamental step that should be done to achieve these goals is taking policies and strategies corresponding to the current situation in the country. In the structure of planning and executive systems governing Iran the process of policymaking and operational programs is determined by the five-year strategic plans of development, and it is directly related to the amount of attention and tendency given to run approaches and strategies like sustainable development, especially sustainable development in rural 
spaces (Afrakhte et al., 2014: 68). Furthermore, one of the most important goals in drawing development plans is the reconstruction of economic, social, cultural and physical structures that can moderate inequalities and make local and regional balance in a country (Shortall, 2008:450; Shortall, 1994; Buller, 2000; Ray, 2000).Thus, in this paper for assist the process of sustainable rural development, we have tried to drawing conceptual model of relation between policies of comprehensive growth in national development plans with economic stability in rural spaces.

\section{SUSTAINABLE DEVELOPMENT}

Decades of experience in planning and progress-oriented actions in political and planning systems resulted in some important achievements such as paying special attentions to the process of sustainable development. Based on a prospective approach, it is true to say sustainable development sought to raise level of knowledge and awareness in human beings towards the Earth's natural resources to set up a sustainable lifestyle for all of them. On the other hand, it is opposing to excessive consumption, waste of resources, ignoring future generations and breaking relations with the past (Zahedi \&Najafi, 2007; Quaddus, 2001; WCED, 1987). In other words, sustainable development can be considered as a process of socioeconomic growth and development which is established based on economic approaches, provided that the total value of accumulations and capital stocks remain constant or non-decreasing forever and at any time (Rao, 2007); this means that total ecological and nonecological capital reserves will be separately preserved and maintained in the infinite time horizon nondecreasingly (figure 1).

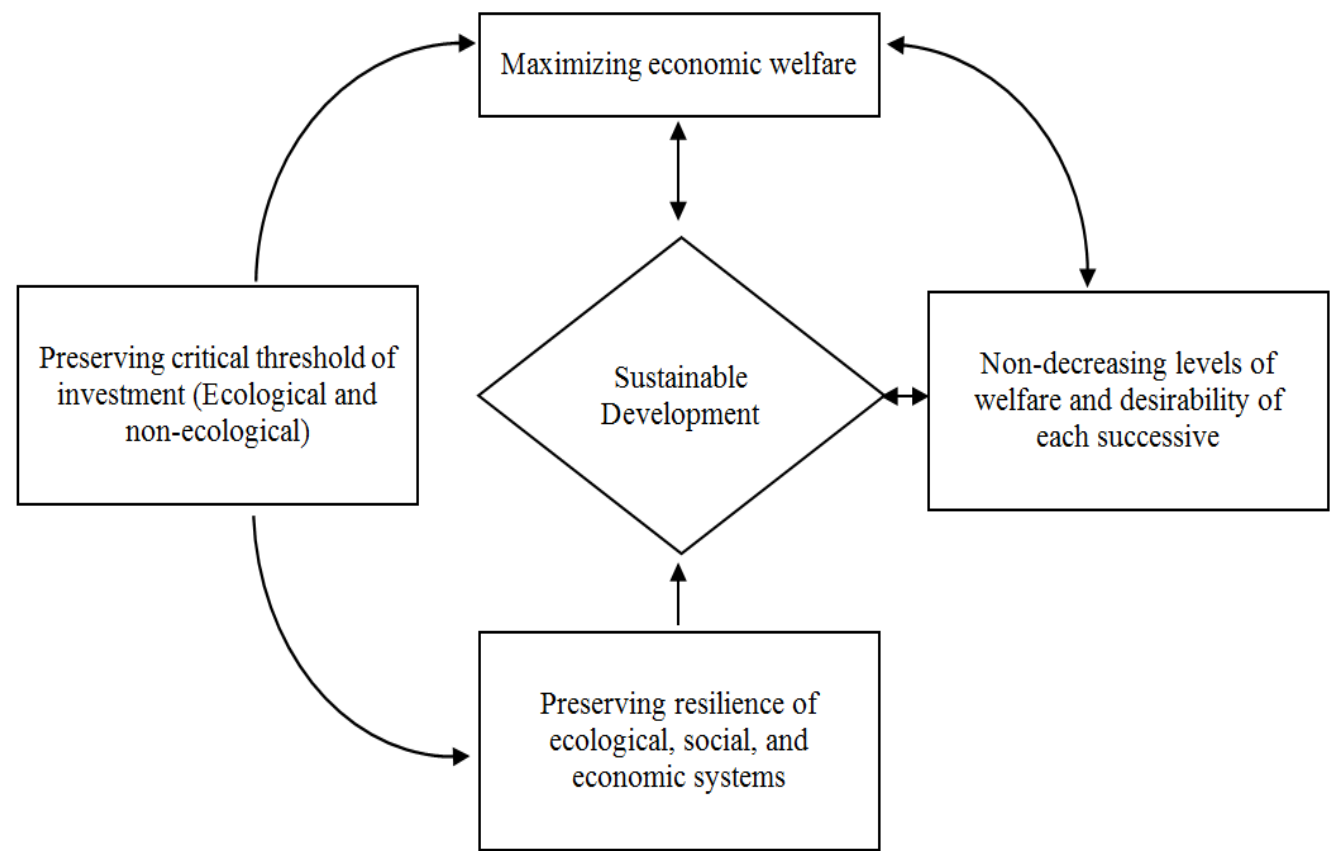

Fig. 1. Mechanisms of sustainable development (Source: Rao, 2007)

\section{RURAL SUSTAINABLE DEVELOPMENT}

The concept of sustainable development of rural settlements, which leads to the rural life improvement of villagers and realization of their ideals and dreams, is considered as one of the essential components in the process of land development (Elands \& Wiersum, 2001; Thompson, 1998). Sustainable rural development is an appropriate approach toward the management and conservation of natural resources and the environment (Lowe \& Ward, 2007) which generally can be defined as a process parallel to the balanced realization of the varied objectives with focusing on social and economic development and environmental conservation in rural spaces (Bruckmeier\& Tovey, 2008). In fact, sustainable rural development is a process of helping villagers through prioritization and activation of their needs, financing to create infrastructures and provide social services, creating justice and equal rights considering local capacities and behaviors against all the previous injustices in order to ensure their security and health (S.A.R.D.F, 2005). So, it can be admitted that sustainable rural development is done with the purpose of pushing people toward the level of life satisfaction and having the freedom of choice and equal rights in getting different opportunities (ESCAP, 1996; Axinn \& Axinn, 1997).

According to the philosophical and operational principles of sustainability, it is necessary for the economic, social, ecological, institutional and spatial processes to be organized as one of the most important aspects in the 
rural development issues to achieve sustainable development through the control and management of the rural area (Varga, 2008). Among these principles, we can say that economy is the fundamental principle of sustainable rural/ spatial development because of the importance and priority of its effect on the mentioned process (Spangenberg, 2000) in a way that the intensification of environmental degradation is considered as one of the inevitable consequences of poor performance by space economy (Ascher\& Healy, 1990; World Bank, 1992; Inter-American Development Bank, 1991). Overall, since the beginning of human creation, man as a major actor in the scene of geographic space has been in additions trying to obtain his important goals such as accessing the maximum production and profits in exchange for the minimum amount of efforts and expenses (Morrill, 1974). Thus, in the present world which is mainly based on the capitalism rules, economy carries a unique role as well as being the basis of the spatial organization (Castells, 2006).

\section{ECONOMIC STABILITY, NEEDED TO ACHIEVE RURAL SUSTAINABLE DEVELOPMENT}

So, "economic stability" is an inevitable strategy that program makers and development authorities should look for solutions to this problem in their planning and spatial-location programs, because not only providing basic arrangements for sustainable development but also sustainability of settlements in rural areas depends directly on it (GhadiriMasoom et al., 2011). Economic stability is defined as the ability to save power and of capital regeneration and evenly maintenance of capitals (Rawls, 1973). In other words, economic stability is connected with a balanced composition of production factors as we can see the increasing improvement of production efficiency besides the deep and strong connections between producers and consumers (Midmore\& Whittaker, 2000). In fact, from a geographical viewpoint we can say that space economy is sustainable when it can provide a consumer-friendly production to supply at any time. This production can consists of goods and services to pristine natural landscapes and even to provide a place of peace and comfort.

Achieving economic stability depends on numerous factors that one of the most fundamental of those beneficial factors is consistent and balanced economic growth in different parts of space and subsection activities. Actually, integrated development of space economic activities within a complementary functional approach in each section can cause into the strengthening and improving the performance of its constituent parts and finally into the process of economic stability (Morgan et al., 2006; Hendrickson \& Heffernan, 2002; Marsden, 2009). As it was mentioned in the general concept of development, development should be done based on an integrated, perfect process to cover all aspects of life and spatial realities, especially in economic aspect (Sarrafi\& Ahmadi Torshizi, 2005).

\section{POLICIES OF COMPREHENSIVE GROWTH IN NATIONAL DEVELOPMENT PLANS FOR ECONOMIC STABILITY}

Adopting leading policies and programs of space economy towards an integrated, comprehensive development, the relocation of resources, increase in production, increase in trade, improvement of institutions, elimination of piles of unfavorable conditions of a social system, and finally realization of a favorable economic development will be possible through the expansion of productive capacity and dominance of a harmonious economic system in a society (Akbari \&Moallemi, 2006).

Moreover, when planning development the important thing that most program makers from different countries have insisted on it, is the maintenance of economic stability and equivalence in favor of inappropriate environment poor people are engaged in (Misra - a, 1986; Misra -g, 1986; Misra, 1980). Thus, regarding the spatial-location aspect we can say that dominance of integrated development in country space depends on strengthening the role and expanding all the constitutive principles of space including both villages and cities, so that establish an optimal spatial organization and national sustainable development is with promoting balancein the economic interaction and production relationship between urban and rural.

In rural spaces, equally economic activities development, contemporaneously the diversification to space economy in these places of living, especially when non-agricultural activities are the main factors that followed by the issues like job production, occupation development, salary increase for poor rural families and rural economic prosperity (World Bank, 2005; World Bank, 2000; World Bank, 2001), is one of the emphasized solutions and successful experiences of international organizations, which is related to the development, because according to the high rate of population growth and farm limitation, rural industries can attract an acceptable number of personnel, decrease the rate of unemployment and make better situations for the countries to be developed by making new job opportunities (Maran,2007). In addition to occupation rate increase, as one of the non-agricultural sectors, it can cause the non-local incomes to be added and it can have an important role in agriculture section modernization, directly and indirectly (Das, 2009). So the elimination lack of balance and differentiation among areas, is necessary to plan the national important program for developing the back warded areas, to make the best situations and equipments for an integrated development. Life quality differences will be 
minimized between in-area and interval-area and omit them finally (Misra at al., 1974). The present conceptual model can be designed based on theoretical discussions (figure 2).

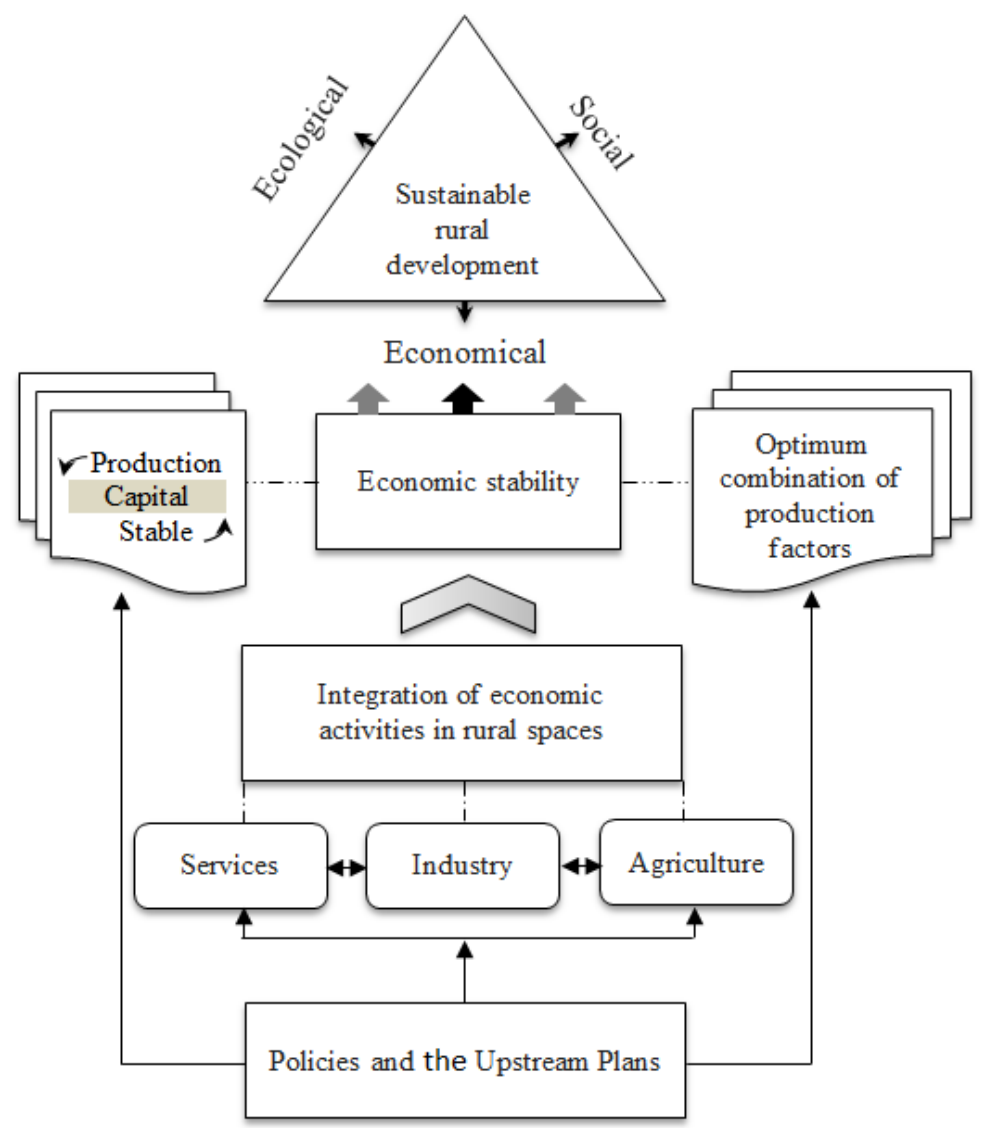

Fig. 2. Conceptual model

\section{REFERENCES}

[1] Afrakhteh, H. Hajipour, M. Gorzin, M. and Nejati, B. (2013), Place sustainable agricultural development programs in Iran: Case study five years after the programs, Journal of strategic policies and macro-First Year, Issue 1, pp. 95-65.

[2] Akbari, N. and Moallemi, M. (2005), Economic integration of the countries of the Gulf area Fary: Using a spatial econometric approach, Journal of Iranian Economic Research, No. 25, pp. 126-109.

[3] Ake, C. (1996), Democracy and Development in Africa, the brookings Institute Washington D.C.

[4] Anriquez, G. and Stamoulis, K., (2007), rural development and poverty reduction: Is agriculture still the key? The Food and Agriculture Organization of the United Nations.

[5] Ascher, W. and R. Healy (1990), Natural Resource Policymaking: A Framework for Developing Countries. Durham: Duke University Press.

[6] Axinn, G. H. \&Axinn, N. W. (1997), Collaboration in Rural Development, a Practioner Hand Book, London.

[7] Bruckmeier, K. \& Tovey, H. (2008), Knowledge in Sustainable Rural Development: From Forms of Knowledge to Knowledge Processes, Journal of SociologiaRuralis, Vol. 48, No. 3, pp. 329-313.

[8] Bruckmeier, Karl \& Tovey, Hilary (2009), Rural Sustainable Development in the Knowledge Society, Ashgate , UK;

[9] Buller, H. (2000), Re-creating rural territories: LEADER in France. SociologiaRuralis 40 (No. 2), 190 200.

[10] Castells, M. (2006), Space of Flows, Geographical Approaches, visit on: http://socgeo.ruhosting.nl/html/files/geoapp/Werkstukken/CastellsFlows.pdf

[11] Dalal-clayton, Barry \& Bass, Stephen. (2002), sustainable development strategies, the international institute for envaironment and development, earthscan publication ltd, londen, sterling, VA. 
[12] Das, K. (2009), Broad - basing Rural Industrialisation in India: Approaches and challenges, Collaborative Research Project on Systems of Innovation for Inclusive Development: Lessons from Rural China and India.

[13] Elands. B.H.M. \&Wiersum, K. F. (2001), Forestry and rural development in Europe: an exploration of socio-political discourses. Forest Policy and Economics, v.3.

[14] ESCAP. (1996), Rural Poverty Alleviation and Sustainable Development in Asia and the Pacific, United Nations, New York.

[15] European Communities Commission. (2007), Rural Development in the European Union: Statistical and Economic Information Report 2007. European Communities Commission: Directorate-General for Agriculture and Rural Development. Office for Official Publications of the European Communities,

[16] Ezeala-Harrison, F. (1996), Economic development: Theory and policy applications, USA: Praeger publishers.

[17] GhadiriMasoom, M. Ziyanushin, M. M. and Khorasani, M. A. (2011), Economic sustainability and its relation to spatial characteristics - Space: A Case Study of a village KuhinKabudarahang city, Journal of Rural Development, No. 2, pp. 29-1.

[18] Hendrickson, M. K. \& Heffernan, W. D. (2002), Opening spaces through relocalisation: locating potential resistance in the weaknesses of the global food system. SociologiaRuralis 42 (4), pp.347-369.

[19] Inter-American Development Bank (1991), Our Own Agenda. Washington, DC: IADB.

[20] Javan, J. Allavizadeh, S. A. M. and Kermani, M. (2011), Diversification of economic activities in rural sustainable development: A case study city Samirom, Iranian Journal of Geographical Society, No. 29, pp. 43-17.

[21] King, B., A. Pizam and Milman, (1983), Social Impacts of Tourism: Host perception, Annals of Tourism Research, 17: $449-465$.

[22] Lowe, P., \& Ward, N. (2007), Sustainable rural economies: some lessons from the English experience, Journal of Sustainable Development, Volume 15, Issue 5, pp. 307-317.

[23] Maran, K. (2007), Problemes of Rural Labor: Issue and Challenges, Cuddalore, Pallavan Book publishing Company Itd.

[24] Marsden, T. (2009), Mobilities, Vulnerabilities and Sustainabilities: Exploring Pathways from Denial to Sustainable Rural Development, Journal of SociologiaRuralis, Vol. 49, No. 2, pp. 131-133.

[25] Misra, R. P. (1986-A), Concept of development: characteristics of a backward society, Bimonthly journal Jahad No. 76, pp. 29-24.

[26] Misra, R. P. (1986-B), Concept of development: Backwardness factors, Bimonthly journal Jahad, No. 77, pp. 11-7.

[27] Misra, R. P. (1986-C), Concept of development: Planning for Development, Bimonthly journal Jahad, No. 78 , pp. 29-24.

[28] Misra, R. P. et al. (1974), Regional development planning in India: A New Strategy, Delhi, Vikas, Chap: 1.

[29] Misra. R. P. (1980), Target Groups and Regional Development, Regional Development Dialogue, Vol 1, No 1.

[30] Morgan, K.; Marsden, T. and Murdoch, J. (2006), Worlds of food: power, place and provenance in the food chain, Oxford University Press.

[31] Morrill, R. L. (1974), the Spatial Organization of Society, Duxbury Press.

[32] Pa`sakarnis, G., \&Maliene, V. (2010). Land readjustment for sustainable rural development In: EURO Mini Conference 5th International Vilnius Conference on Sustainable Development: Knowledge-Based Technologies and OR methodologies for Strategic Decisions of Sustainable Development, Vilnius, Lithuania, pp.169-174.

[33] Quaddus, M. (2001), modeling sustainable development planning: A multi criteria decision conferencing approach, Environment International, 27.

[34] Rao, K. N. (2007), Sustainable Development: Economicsandmechanisms, translation ofAhmadrezaYavari in parsian, Tehran University Press.

[35] Rawls, J. (1973), Distributive justice. In F. S. Phelps (ed), Economic Justice. Baltimore: Penguin Book.

[36] Ray, C. (2000), The EU LEADER programme: rural development laboratory. SociologiaRuralis 40 (No. 2), $163-172$.

[37] Rezvani, M. R. (2003), rural development: the importance and the eradication of poverty, Andishe Journal, Year IX, No. 4, 3, pp. 275-262.

[38] Sarrafi, M. and Ahmadi Torshizi, M. (2004), Capacity and Development, Geographical Society Iranian Journal, number 3, pp. 65-51.

[39] Shortall, S. (1994), The Irish rural development paradigm - an exploratory analysis. Economic and Social Review 25 (No. 3), 233-261. 
[40] Shortall, S. (2008), Are rural development programmes socially inclusive? Social inclusion, civic engagement, participation, and social capital: Exploring the differences, Journal of Rural Studies 24, 450-457.

[41] SoltaniMoghadas, R. (2013), Framhlycurrentstatus ofinvestmentinruralareas, Journal of GeographicSociety ofIran, No. 37, pp.170-157.

[42] South African Rural Development Framework- S.A.R.D.F (2005), available on http:// cbdd. Wsu. Edu/ kew/content/ cdoutput/tr501/page58.htm.

[43] Spangenberg, J. H. (2000), Sustainable Development Concepts and Indicators, Sustainable Europe Research Institute, Vice President, visit on: http://web205.vbox01.inode.at/Data/personendaten/js/catxta.pdf.

[44] Taherkhani, M. (1993), Rural Industrialization, Ministry of Agriculture, Tehran.

[45] Thompson, P. B. (1999), sustainability as norm, available in: http: // scolar. Lib. Vt. Edu/ ejournals / spt / v2n2 / Thompson. Html.

[46] Todaro. M. P. (1992), Economic for Development World. An Introdaction to Principles, problems, and policies for Development, Longman Publishing, NewYork.

[47] Torjman, S. (2000), The Social Dimension of Sustainable Development, Caledon Institute Social Policy.

[48] Varga, E. (2008), the challenges of sustainable rural development towards engineering education, university of faculty of engineering/ department of pedology, pecs, hungary.

[49] Vidican, G. (2009), Assessing land reallocation decisions during transition in Romania. Land Use Policy 26, 1080-1089.

[50] World Bank (1992), World Development Report 1992: Development and the Environment. New York: Oxford University Press.

[51] World Bank. (2000), Gender, Poverty, and; Nonfarm Employment in Ghana and Uganda; the World Bank; Development Research Group, Rural Development and Human Development Network; Social Protection Team, June 2000.

[52] World Bank. (2001), Rural Non-Farm Activities; and Rural Development; From Experience towards Strategy.

[53] World Bank. (2005), Rural Reform, Nonfarm Development, and Rural Modernization in China; Dong Fureng.

[54] World Commission for Environment and Development WCED, (1987). 'Our Common Future', Oxford University Press).

[55] Zahedi, S. and Najafi, Gh. (2007), Concept of Sustainable Development, Journal of Humanities Teacher, No. 4. 